\title{
The role of clean technology research in disaster debris management
}

\author{
Callie W. Babbitt ${ }^{1}$
}

Published online: 6 June 2019

(c) Springer-Verlag GmbH Germany, part of Springer Nature 2019

Each year, communities around the world are devastated by natural disasters. Floods, hurricanes, tornadoes, earthquakes, tsunamis, volcanic eruptions, wildfires, mudslides, and extreme weather events are responsible for death, displacement, and devastation to social, economic, and ecological systems. In 2018, the costs of disasters in the USA alone were estimated to exceed $\$ 91$ Billion, according to the National Centers for Environmental Information, a division of the US National Oceanic and Atmospheric Administration (NOAA 2019). At a global scale, the World Health Organization estimates that natural disasters are responsible for 90,000 deaths each year and for health impacts to almost 160 million people worldwide (WHO 2019). These effects show no sign of slowing, as unchecked climate change is expected to increase the magnitude and frequency of many disaster events.

The world's attention to a natural disaster usually begins to wane after the immediate risk has passed and news coverage moves on to other events. But it is at this point that a region begins to face the challenges of recovery and rebuilding, including the daunting task of dealing with debris and environmental damage left behind. The magnitude of these debris management challenges in recent years is staggering. According to the US Federal Emergency Management Agency (FEMA 2006), the single most catastrophic natural disaster in US history was Hurricane Katrina, which resulted in more than 99 million cubic yards of debris that cost more than $\$ 3.7$ billion to remove and manage. Not only are these waste streams an added financial burden, they also magnify the temporal and geographic scale of resulting environmental impacts. After Japan's 2011 Tōhoku earthquake and tsunami, over five million tonnes of material was swept into the Pacific Ocean, some of which ultimately made landfall in US coastal areas in the years that followed (Murray et al. 2018).

Callie W. Babbitt

cwbgis@rit.edu

1 Rochester Institute of Technology, Rochester, NY, USA
Post-disaster debris may include relatively benign materials like construction residues (steel, wood, concrete), vegetative materials (trees, shrubs, soil), and general wastes (household belongings or trash), along with potentially harmful waste streams, such as spoiled food, electronics and appliances, and household and industrial hazardous wastes. Some types of disasters may leave behind crushed but recyclable debris streams while others generate ashladen, water-logged, or biologically or chemically contaminated wastes whose condition further confounds debris management efforts. The volume, heterogeneity, and potential risks associated with handling disaster debris, along with the urgency of clearing roadways and destroyed infrastructure, make separation and sustainable management difficult. As a result, much of this waste stream is often relegated to landfills, leading to secondary environmental impacts from resulting air and water emissions and induced demand for new resource extraction.

While these challenges are significant, they also point to an opportunity for sustainable innovations in post-disaster debris management that can achieve social, economic, and environmental co-benefits. Exploring this opportunity was the theme of a recent workshop I attended on the topic of "Post-Disaster Materials and Environmental Management." Funded by the US National Science Foundation (Award \#1922539), the event brought together researchers, government agencies, and private-sector companies from across the USA to collaboratively identify critical research needs surrounding sustainable management of disaster debris. The workshop organizers anticipate a full report of findings, but I will share here three themes that may be particularly relevant to readers of Clean Technologies and Environmental Policy:

1. Effective post-disaster debris management hinges on effective pre-disaster planning, including the ability to proactively estimate the type, source, volume, and location of debris expected to be generated. In a past issue of this journal, Tabata et al. (2016) demonstrate a methodology for predicting debris using household product ownership data, leading to better understanding of 
future waste challenges and needed recycling infrastructure capacity. Expanding research in this domain can address related challenges of integrating publicly available data from multiple disparate sources, accounting for debris that may emerge in the future such as smart home devices and lithium-ion batteries, and adding geospatial analysis to debris forecasts (e.g., Leader et al. 2018).

2. Expanding capacity for disaster debris management requires advances in reuse and recycling technologies, including innovative building materials that prevent or minimize debris generation from the start, new imaging and screening technology that can quickly and accurately characterize debris composition and properties (Axel et al. 2016), and scalable, automated systems that can screen, classify, sort, and pre-treat debris onsite or efficiently transport debris to off-site processing locations (Amato et al. 2019). Future clean technology research will play a key role in creating, validating, and deploying these systems at varied scales and regional contexts.

3. Optimizing the economic and environmental benefit from materials and energy recovered from disaster debris requires concurrent development of end-use applications and markets. This development will need to include fundamental advances in understanding how chemical and physical properties and quality of materials separated from debris may affect performance of the products in which they are ultimately used (e.g., recovered concrete used in new infrastructure construction) and novel models that can quantify how sudden and periodic surges of surplus materials may impact existing recycling markets and long-term supply chains (Brown et al. 2011).

These themes reflect critical research questions that contributors to Clean Technologies and Environmental Policy are well-poised to answer. However, the broader arena in which such innovations would be deployed should also be considered. Fundamental discoveries and new technologies will face barriers to adoption, including public acceptance, stakeholder coordination, regulatory constraints, and economic competitiveness. As such, research under the "environmental policy" theme of this journal's scope is also critical to understand the pathways by which research solutions can achieve broad impact. It is my hope that researchers embrace this challenge: as the frequency and magnitude of disasters grow globally, the likelihood that our families, communities, and colleagues will be impacted also increases, underscoring the importance and urgency for new solutions.

\section{References}

Amato A, Gabrielli F, Spinozzi F, Galluzzi LM, Balducci S, Beolchini F (2019) Strategies of disaster waste management after an earthquake: a sustainability assessment. Resour Conserv Recycl 146:590-597

Axel C, van Aardt JA, Aros-Vera F, Holguín-Veras J (2016) Remote sensing-based detection and quantification of roadway debris following natural disasters. In: Laser radar technology and applications XXI. International Society for Optics and Photonics, vol 9832, p 98320C

Brown C, Milke M, Seville E (2011) Disaster waste management: a review article. Waste Manag 31(6):1085-1098

FEMA (2006) By the numbers-one year later. Release number: HQ06-127Numbers. https://www.fema.gov/news-release/2006/08/22/ numbers-one-year-later

Leader A, Gaustad G, Tomaszewski B, Babbitt C (2018) The consequences of electronic waste post-disaster: a case study of flooding in Bonn, Germany. Sustainability 10(11):4193

Murray CC, Maximenko N, Lippiatt S (2018) The influx of marine debris from the Great Japan Tsunami of 2011 to North American shorelines. Mar Pollut Bull 132:26-32

NOAA National Centers for Environmental Information (NCEI) U.S. Billion-Dollar Weather and Climate Disasters (2019) https://www. ncdc.noaa.gov/billions/

Tabata T, Zhang O, Yamanaka Y, Tsai P (2016) Estimating potential disaster waste generation for pre-disaster waste management. Clean Technol Environ Policy 18(6):1735-1744

World Heath Organization (WHO) (2019) Environmental health in emergencies. https://www.who.int/environmental_health_emerg encies/natural_events/en/

Publisher's Note Springer Nature remains neutral with regard to jurisdictional claims in published maps and institutional affiliations. 